\title{
Quercetin in the treatment and prevention of COVID-19
}

\section{COVID-19 tedavi ve profillaksisinde Quercetin}

\author{
Şeyma Taştemur ${ }^{1}$, Hillmi Ataseven ${ }^{2}$
}

' Department of Internal Medicine, Sivas Numune Hospital, Sivas, Turkey

${ }^{2}$ Department of Internal Medicine, Discipline of Gastroenterology, Faculty of Medicine, Sivas Cumhuriyet University, Sivas, Turkey

Corresponding author: Şeyma Taştemur, MD., Department of Internal Medicine, Sivas Numune Hospital, Sivas, Turkey

E-mail: yaman_seyma@yahoo.com

Received/Accepted: May 20, 2021 / July 01, 2021

Conflict of interest: There is not a conflict of interest.

\begin{abstract}
SUMMARY
Coronavirus Disease-19 ( COVID-19) is a disease that started at the end of 2019 and continues to affect all the world as a pandemic. There is no definitive cure for COVID-19 yet. The disease is characterized by excessive immune activity, inflammation and coagulopathy. Many agents have been tried for treatment and prevention. Flavonoids are valuable natural food components with antioxidant, anti-inflammatory and anticoagulant properties. Quercetin, the best known flavonoid, is one of the most studied and beneficial one. Quercetin, which has been shown to be effective in many viral diseases, is mainly used in diseases such as cardiovascular disease and diabetes, which are associated with chronic inflammation. it is an important candidate for the treatment and prophylaxis of COVID-19, thanks to its powerful anti-inflammatory, antioxidant and immune-modulating effects.
\end{abstract}

Keywords: Quercetin, COVID-19, Treatment

Şeyma Taştemur

Hilmi Ataseven

ORCID IDs of the authors:

Ş.T. 0000-0002-9013-6395

H.A. 0000-0001-5458-509X

ÖZET

Coronavirüs Hastalığ1-19 (COVID-19), 2019 y1lının sonlarında başlayan ve pandemi olarak tüm dünyayı etkisi altına almaya devam eden bir hastalıktır. Henüz COVID-19 için kesin bir tedavi yoktur. Hastalık aşırı immünite aktivitesi, inflamasyon ve koagülopati ile karakterizedir. Tedavi ve profilaksi için birçok ajan denenmiştir. Flavonoidler, antioksidan, antienflamatuar ve antikoagülan özelliklere sahip değerli doğal gıda bileşenleridir. En iyi bilinen flavonoid olan Quercetin, en çok çalışılan ve faydası görülenlerden biridir. Birçok viral hastalıkta etkili olduğu gösterilen Quersetin, ağırlıklı olarak kardiyovasküler hastalık ve diyabet gibi kronik inflamasyonla ilişkili hastalıklarda kullanılmaktadır. Güçlü antienflamatuar, antioksidan ve immünmodülatör etkileri sayesinde COVID-19 tedavisi ve profilaksisi için önemli bir adaydir.

Anahtar sözcükler: Quercetin, COVID-19, tedavi

\section{INTRODUCTION}

After their discovery in the 1960 s, Coronaviruses were associated with the outbreaks; Severe Acute Respiratory Syndrome (SARS) in 2003 and Middle East Respiratory Syndrome (MERS) in $2012(1,2)$. They came to the fore again with the cases of viral pneumonia with unexplained and severe illness in December 2019, in Wuhan, China. This new type of coronavirus was named as novel coronavirus-19
(nCoV19) by the World Health Organization (WHO) on January 12, 2020. On February 11, 2020, the disease was named as COVID-19 (3). WHO declared a pandemic on March 11, 2020, as a result of the disease that spread in China and then all over the world within a month (4). This date is also the date when the first case was seen in Turkey. 
Currently, there is no definitive treatment for this disease, whose vaccination applications continue. However, many agents are being tested and evaluated in the treatment and prophylaxis of COVID-19. Quercetin, a well known flavonoid, which has been proven in powerful antiinflammatory, antioxidant and antiviral activities, seems promising as an anti-COVID-19 treatment option in the light of the data obtained.

\section{SARS-CoV2}

Coronaviruses are enveloped, positively polarized, single-stranded RNA viruses (5). When the virus enters the host cell, viral RNA reaches the nucleus for replication. Viral mRNA is used for the biosynthesis of viral proteins. Later, new viral structures are created. Coronaviruses consist of spike protein, membrane, envelope and nucleocapsid (6). Spike protein is responsible for binding to host cell receptors and the cell membrane. SARS-CoV2 is structurally very similar to SARS-CoV. Angiotensin converting enzyme 2 (ACE2) has been defined as the receptor for SARS-CoV2 (7). Tissues with ACE2 expression are at high risk for COVID-19 (8). This diversity of distribution also explains the multiple organ failure that may develop during the course of the disease (9). Since ACE2 expression is higher in the lung epithelial cells in the alveolar space, the entry and damage of the virus is significant in lungs $(10,11)$.

\section{Flavonoids}

Flavonoids are natural herbal metabolites containing benzopyrone ring in polyphenolic structure, which are generally found in fruits, vegetables and various beverages $(12,13)$. In nature flavonoids function as UV filters, signal molecules, phytoalexins, and detoxifying/antimicrobial agents for the plants and protect them from all biotic/abiotic stresses (14).

Most flavonoids are known as flower pigments. However, their presence in nature is not limited to flowers, they are obtained from many parts of plants (15). Basically, fruits, leaf stems, roots, grains, nuts, vegetables, flowers and seeds are rich sources of flavonoids. More than 10,000 flavonoid compounds have been isolated and identified $(16,17)$.

Flavonoids are associated with positive health effects and are essential ingredients in a variety of dietary, pharmaceutical, medical, and cosmetic applications (18). These flavonoids, which are very valuable dietary components known to have many beneficial biochemical and antioxidant effects, are used in the treatment of many diseases such as cancer, Alzheimer's disease, and atherosclerosis $(19,20)$. They are therapeutic agents with anticancer, antioxidant, antibacterial, antiviral, antiangogenic, antimalarial, neuroprotective and antiproliferative activities. (21-25). They have become particularly popular by preventing cardiometabolic diseases and slowing down the decline in cognitive performance due to aging process $(26,27)$.

\section{Quercetin}

Flavonoids are subdivided into flavones, flavonols, isoflavones, and anthocyanidins. These subgroups are quite common in nature (28). For example, narigenin and hesperetin are found in citrus fruits and grapes, while anthocyanidins and quercetin are found in mulberry $(29,30)$.

The most studied flavonols are kaempferol, quercetin, myricetin and fisetin. Onions, cabbage, lettuce, tomatoes, apples, grapes, and some other fruits are rich sources of flavonols. Besides fruits and vegetables, tea and red wine are also sources of flavonols. Flavonols are the most common dietary group of flavonoids, and quercetin can be shown as the best example of this group (31). Quercetin is most commonly found in berry fruits, but also in buckwheat, onion, kale, broccoli, apple, orange, black tea, and green tea (32).

Flavonoids are mostly obtained from the consumption of fruits, vegetables and tea. Daily intake is known to range from 5 to $100 \mathrm{mg} /$ day. Quercetin and glycosides are about $75 \%$ of dietary flavonoids (33).

In nature, quercetin is found predominantly in Oglycosidic form. Apart from this form, a monosaccharide such as glucose / galactose / rhamnose or a disaccharide, which is usually rutinose, can also be found attached to the 3,7 and 4 'positions. Although the sugar part is usually $\mathrm{O}$ glycosidically bound, it can sometimes be found as C-glycosidic. Quercetin glycosides are most frequently seen as 4'-O-glycosides in onions (34).

Epidemiological studies show that a diet rich in flavonoids is closely related to a reduction in the incidence of various diseases associated with aging (35). As a dietary ingredient, quercetin has unique biological properties that improve mental and physical performance and reduce the risk of infection (36).

Quercetin, like other flavonoids, is known to inhibit lipid peroxidation, platelet aggregation, capillary permeability and stimulate mitochondrial biogenesis in addition to showing anticancer, antiinflammatory, antiallergic, antioxidant, 
antidiabetic, vasoprotective, antihypertensive, hypolipidemic, antithrombotic activities (37-42).

\section{Effects of Quercetin on SARS-CoV2}

\section{Viral Features}

There is a large literature supporting the antiviral properties of quercetin, both in-vitro and in-vivo. Initial in-vivo studies, a positive effect was observed with treatment with quercetin in immunocompetent mice infected with Mengo virus (43).

In-silico and in-vitro studies have shown that quercetin can interfere with various stages of coronavirus entry and replication cycle, such as papain-like protease (PLpro), 3C-like protease (3CLpro) and nucleoside-triphosphatase (NTPase) / helicase. Combination of quercetin with vitamin $\mathrm{D}$ and vitamin $\mathrm{C}$ is known to exert synergistic antiviral and immunomodulatory effects (44).

Effects on many respiratory system viruses were observed in other cell culture studies. It suppresses cytopathic effects caused by rhinovirus, ecovirus (types 7, 11, 12 and 19), coxacivirus (A21 and B1), and polioviruses (type 1 Sabin) $(45,46)$.

In rhinovirus infected mice, quercetin treatment reduces viral replication and alleviates virusinduced airway cholinergic hypersensitivity (47).

In a randomized, double-blind, placebo-controlled study evaluating individuals over the age of 40 who received $1000 \mathrm{mg}$ of quercetin, it was found that the quercetin group had a $36 \%$ lower severity of upper respiratory tract infection (URTI) compared to the control group, and the duration of URTI was $31 \%$ shorter. (48).

Quercetin stops viral binding and penetration into the host cell and prevents infection with herpes simplex virus 1,2 (HSV-1, HSV-2) and acyclovirresistant HSV-1 by suppressing NF-jB activation required for HSV gene expression $(49,50)$.

It has been shown that athletes taking quercetin supplements are protected against stress-induced URTI (51).

In-vitro data revealed that quercetin halts endocytosis by inhibiting phosphatidyl inositol 3kinase (PI3K), suppresses transcription and translation, and enhances viral clearance by stimulating the mitochondrial antiviral response. Thus, it has been shown that quercetin can inhibit viral replication of influenza virus by interfering with the 3 stages of viral replication (52).

Quercetin; Since it inhibits polymerase, protease, reverse transcriptase, DNA gyrase and binds viral capsid proteins, it has been tested on various types and models in many studies $(53,54)$.

The use of vitamin $\mathrm{C}$ and quercetin has been found effective in COVID-19 for both prophylaxis and treatment in high risk individuals. (55).

One of the first studies investigating the effect of quercetin on coronaviruses was conducted in 1990, and it was shown that the infectivity of human and bovine coronaviruses decreased by $50 \%$ with a dose of $60 \mu \mathrm{g} / \mathrm{mL}$ quercetin (56).

Luteolin and quercetin have been shown to prevent the entry of SARS-CoV into host Vero cells (57).

SARS-CoV, defined in 2003, is a single-stranded RNA virus that uses ribosome regions to encode 2 replicase glycoproteins, polyprotein 1a (PP1a) and polyprotein 1b (PP1b), which mediate viral replication (58). Once these precursor glycoproteins are produced, the process of protease-mediated lysis begins (59).

The inhibitory effects of quercetin isolated from a yeast species named Pichia pastoris on 3CLpro have been demonstrated. Quercetin-3-O- $\beta$ galactoside binds to 3CLpro of SARS-CoV and inhibits its proteolytic activity (60). The binding sites of SARS-CoV2 and SARS-CoV 3CL proteases with quercetin are the same (61). In addition, it has been shown that quercetin binds more strongly to spike protein, ACE2, RNAdependent RNA polimerase (RdRp) and PLpro than 3CLpro (62). In these contexts, it is predicted that quercetin has a protective and therapeutic role against COVID-19 as well as its known antioxidant and anti-inflammatory properties.

Quercetin also modulates the cellular unfolded protein response (UPR). Since coronaviruses can use UPR to complete all replication cycles, Quercetin can exhibit antiviral activity by modulating this pathway (63).

Coronaviruses are sensitive to the inhibitory effects of zinc, which can prevent viral entry into cells and reduce coronavirus virulence. Quercetin also functions as a zinc ionophore and has been shown to facilitate transport of zinc across lipid membranes. This could theoretically increase the antiviral effects of zinc (64-67).

3CLpro is also essential for MERS-CoV replication and as in SARS-CoV and SARS-CoV2 Quercetin inhibits MERS-CoV's 3CLpro (68).

In a study in which in-silico modelling of the interaction between SARS-CoV2 spike protein and ACE2 protein was performed, quercetin was identified as one of the 5 most effective compounds 
among drugs, metabolites and natural products that suppress the initial stage of infection (69). In a study conducted in the light of this hypothesis, quercetin demonstrated an anti-infection effect in a cell-virus model. Besides, it inhibited 3CLpro of SARS-CoV in-vitro (70).

As a genomic structure, it can be said that SARSCoV2 is $79 \%$ identical to SARS-CoV (71). Therefore, it is not surprising that quercetin shows similar activity in SARS-CoV2.

In evaluations using gene set enrichment assays (GSEA), vitamin $\mathrm{D}$ and quercetin have been identified as mitigating agents for COVID- 19 . Quercetin affects the functions of $85 \%$ of the target proteins by making $30 \%$ change in the human protein gene coding targeted by SARS-CoV2. Similarly, vitamin D provides a $70 \%$ modification in these proteins with the $25 \%$ change made in the genes of the SARS-CoV2 target proteins. The target protein change in vitamin $\mathrm{D}$ use with quercetin was observed at a rate of 93\% (72).

In a clinical study conducted with COVID-19 patients, in combined use of quercetin, zinc, bromelain and vitamin $\mathrm{C}$, positive effects were observed (73).

Quercetin has low bioavailability and therefore requires special formulations to achieve effective blood levels. A clinical trial is being conducted using the phytosomal form of quercetin (74).

Considering the bioavailability problem, it is thought that the use of diluted quercetin in low doses as nasal spray in its early stages may prevent viral entry into the cell and provide less disease progression and hence hospitalization rate (75).

Quercetin, with its well-known pharmacokinetics, absorption, distribution and metabolism properties, is a potential agent for antiviral therapies based on viral protease inhibition, as it effectively suppresses enzymes essential for replication in coronaviruses.

\section{Immunity and Inflammation}

The main elements of innate immunity in the respiratory tract are epithelial cells, alveolar macrophages and dendritic cells. (76). $\mathrm{T}$ cell mediated immune response occurs as a result of antigen presentation of dendritic cells and macrophages. The cells involved in the response are $\mathrm{CD} 8+$ and $\mathrm{CD} 4+\mathrm{T}$ cells. $\mathrm{CD} 4+\mathrm{T}$ lymphocytes activate $\mathrm{B}$ lymphocytes and provide virus-specific antibody production, while CD8 + T lymphocytes kill virus-infected cells (77). Cytokine release from these cells also has an important role in the immune response and thus the severity of the disease. Studies Studies have revealed an increase in plasma levels of interleukin-1 $\beta$ (IL-1 $\beta)$, interleukin-1 receptor antagonist (IL-1RA), interleukin-2 (IL-2), interleukin-7 (IL-7), interleukin-8 (IL-8), interleukin-10 (IL-10), interferon-y (IFN-y), monocyte chemoattractant peptide-1 (MCP-1), macrophage inflammatory protein-1A (MIP-1A), macrophage inflammatory protein-1B (MIP-1B), granulocyte colony stimulating factor (G-CSF) and tumor necrosis factor- $\alpha$ (TNF- $\alpha$ ) in COVID-19 patients. These levels were found to be significantly higher in patients followed up in the intensive care unit compared to other inpatients. (78). In particular, interleukin-6 (IL-6) has been shown to be the dominant cytokine in macrophage activation syndrome (MAS) and cytokine storm (79). Again, involvement of more than $50 \%$ of the lung parenchyma in patients with acute respiratory distress syndrome (ARDS), was found to be associated with high IL-6 (80).

Quercetin has been reported as a substance known to have potent and long-lasting anti-inflammatory capacity (81). Quercetin has anti-inflammatory potential that can be observed in different cell types in both animal and human models (82-89).

In-vitro studies using various cell lines have show that quercetin suppresses lipopolysaccharide (LPS) -induced TNF- $\alpha$ production in macrophages and LPS-induced IL-8 production in lung A549 cells (83). Moreover, it has been shown that quercetin may decrease the mRNA levels of LPS-induced TNF- $\alpha$ and interleukin- $1 \alpha$ (IL- $1 \alpha$ ) in glial cells (84).

Quercetin suppresses the production of inflammation-producing enzymes cyclooxygenase (COX) and lipoxygenase (LOX) $(85,86)$. Proinflammatory cytonkines have also been shown to reduce the release of tryptase and histamine (87). In a study, anti-inflammatory activity was demonstrated through a decrease in the expression of vascular cell adhesion molecule-1 (VCAM-1) and CD80 (88). The immunomodulatory and immunosuppressive effects of quercetin, on dendritic cell functions have been shown (89).

Quercetin dose-dependently decreases messenger RNA, intracellular adhesion molecule-1 (ICAM1), IL-6, IL-8 and MCP-1 levels (90).

While increasing the production of IFN- $\gamma$, it decreases the production of interleukin-4 (IL-4). With these properties, it can be said that quercetin is a valuable flavonid with beneficial immunomodulatory effects (91). 
Quercetin prevents TNF- $\alpha$ from activating signal transmission pathways such as nuclear factor- $\mathrm{kB}$ $(\mathrm{NF}-\mathrm{\kappa B})$, which are powerful triggers of inflammation and cytokine storm observed in COVID-19. Quercetin also increases the peroxisome proliferator-activated receptor $\gamma$ (PPAR $\gamma$ ) activity, which is antagonist with NF- $\kappa B$. This is one of its indirect anti-inflammatory effects. Thanks to these two mechanisms, TNF- $\alpha$-mediated activation of inflammation cascades is prevented $(92,93)$.

It is known that SARS-CoV2 activates NOD-, LRR- and protein containing pyrin domain 3 (NLRP3) inflammasome $(94,95)$. Among many flavonoids, quercetin differs in-vitro by reducing the NLRP3 inflammatory signaling pathway and gene expression of NF-kB, TNF- $\alpha$, IL- 6 , IL- $1 \beta$ and interleukin-18 (IL-18) (96).

It has been shown in obese individuals, that genes related to interferon-mediated antiviral activity are expressed more with the use of an herbal supplement containing $1000 \mathrm{mg}$ of quercetin (97). In another study conducted with obese patients with iron deficiency anemia, quercetin; It has been shown to reduce the level of IL- 6 , which is an inflammatory marker (98).

$25 \mu \mathrm{M}$ quercetin suppressed the release of IL-1 $\beta$, IL-6, IFN- $\gamma$ and TNF- $\alpha$ in human whole blood treated with LPS. Its demonstration of inhibiting proinflammatory cytokines is important for the treatment of many viral diseases. TNF- $\alpha$ serum levels significantly decreased in individuals who received a treatment / support regimen of $150 \mathrm{mg}$ quercetin daily for 6 weeks (37).

Animal coronavirus models have shown that mast cells located in the respiratory submucosa may play a mixed role, including the generation of $\mathrm{T}$ helper 2 (Th2) proinflammatory cytokines under the influence of viral stimulation and the release of immunoglobulin E, a type of antibody associated with a Th2-type immune reaction (99).

It has been clinically demonstrated that quercetin regulates human mast cell degranulation and restricts the release of cytokines from these cells, which may be beneficial in cytokine storm $(100,101)$.

Quercetin has antioxidant and anti-inflammatory roles, modulating signal pathways associated with post-transcriptional modulators affecting postviral recovery (102).

\section{Oxidative Stress and Mitochondrial Damage}

Helicases of SARS-CoV2 contribute to replication with ATP hydrolysis that can occur in the presence of iron. Sufficient amount of iron must be present in host cells for viral replication. The immune system creates a response by reducing the bioavailability of this iron to restrict viral replication. Therefore, reducing the iron of the cell will create an antiviral effect. Hyperferritinemia seen in COVID-19 is a biomarker for cytokine storm. The main role of ferritin during infections is to reduce its cellular level by storing iron. In addition, the increase in ferritin results in macrophage activation and secretion of various inflammatory cytokines. The process of ferroptosis, a kind of programmed non-apoptotic cell death that develops due to this iron accumulation, has been recently described (103).

Ferroptosis causes an irreversible change in mitochondrial morphology. Mitochondria are the basis of cellular oxidative homeostasis. Irregularity in iron metabolism triggers the formation of reactive oxygen radicals and increases oxidative stress. Increased inflammatory / oxidative stress can lead to mitochondrial dysfunction, leading to ferroptosis, platelet damage and eventually multiorgan failure (104).

Extracellular mitochondria, especially platelet mitochondria, are mediators associated with thrombosis formation. Moreover, a mitochondria that has lost its functionality will increase the production of free oxygen radicals by causing iron accumulation. Increased oxygen radicals will cause mitochondrial damage, microbiota dysbiosis and platelet dysfunction (105). Since mitochondria can regulate the immune system in stressful conditions such as viral infections, they can increase inflammation. This imbalanced immune response causes microbiota dysbiosis. Mitochondria are also known to alter the microbiota by modifying intestinal immune cells, epithelial cells and enterochromaffin cells (104). Both thrombosis and dysbiosis are important issues in the pathogenesis of COVID-19 and since these issues need to be addressed in more detail, they will be discussed in separate sections.

SARS-CoV2, like other RNA viruses, can trigger oxidative stress (106). This can be controlled by detecting oxidative stress markers from the blood of patients diagnosed with COVID-19, as was previously seen in HIV samples (107).

It is possible to talk about an oxidative storm in addition to the cytokine storm seen in patients with 
COVID-19. The destructive effects of large amounts of free oxygen radicals contribute to lipid peroxidation and protein oxidation, damage to pulmonary alveolar membranes and hyalinization (108).

The elderly, diabetic, or those with cardiovascular disease are already under a certain oxidative stress. Viral infections increase this stress even more. This gives us an idea of why the risk of disease severity increases in elderly and / or those ith comorbidities in COVID-19 (109).

In a study in which the level of free oxygen radicals in sputum samples was determined with a real-time electrochemical diagnosis system with biochemical sensitivity, it was found that this level increased in patients with COVID-19 with extensive lung involvement (110).

In addition to supplements such as $\mathrm{N}$-acetyl cysteine, vitamin $\mathrm{C}$, vitamin $\mathrm{E}$, zinc and selenium; polyphenols are also recommended to reduce oxidative stress caused by COVID-19 and to minimize damage (111).

IL- 6 and TNF- $\alpha$ increase superoxide production in neutrophils, and hydrogen peroxide stimulates the release of IL-6 (112-114).

Free oxygen radicals, which are the products of cytokine storm elements, are among the important responsible for tissue and organ damage (115).

Although the most commonly used antioxidant supplements today are vitamin $\mathrm{C}$ and vitamin $\mathrm{E}$, the antioxidant activity of flavonoids is more pronounced than those of these two vitamins (116).

When quercetin is present in the blood, it contributes to vascular health and its conjugated form reduces the risk of cardiovascular diseases. Quercetin and its derivatives provide protection against stroke by preventing thrombosis (117).

Dihydro-quercetin, a dihydroxyflavone, has been observed to reduce free oxygen radical production and lipid peroxidation, and increase the biological functions of antioxidant enzymes in animal models (118).

Quercetin is a potent antioxidant that works as a free radical scavenger by donating 2 electrons through o-quinone / quinone methide in bothinvitro and in-vivo $(119,120)$ studies.

In an animal experiment on influenza (H3N2), onset of infection; catalase has been associated with decreased concentrations of glutathione and superoxide dismutase (antioxidants) in the lung. Quercetin supplementation given concurrently with virus inoculation provided significant increases in pulmonary levels of these antioxidants (121).

The onion species named Allium cepa has a rich content of quercetin derivatives and has both antioxidant and antidiabetic effects due to its inhibitory effect on protein tyrosine phosphatase 1B (PTP1B) and its effects that increase glucose uptake (122-124).

\section{Thrombosis}

COVID-19 is a disease in which procoagulant factors and thus coagulability increase and thromboembolism can be seen. In a study that revealed the relationship of coagulation with ARDS pathogenesis, tissue factor and plasminogen activator inhibitor-1 levels were found to be significantly higher in patients with ARDS than those without ARDS (125).

The significant increase in D-dimers is thought to be due to intense inflammation inducing intrinsic fibrinolysis in the lung. This bi-directional immuno-thrombosis model reveals that heparin shows both anticoagulant and anti-inflammatory activity by inhibiting thrombin (126).

Many cytokines secreted in COVID-19 are prothrombotic. In particular, interleukin-6 (IL-6) has been found to be associated with increased fibrinogen levels $(127,128)$.

In in-vitro human models of SARS-CoV, infected mononuclear cells expressed high levels of procoagulant genes, including fibrinogen, serine protease inhibitors, tissue factor, and factor II and factor $X(129,130)$. The cells also promote effects such as platelet activation and aggregation, endothelial dysfunction and vasoconstriction by increasing gene expression for Toll-like receptor 9 and thromboxane synthase. Other platelet activation mechanisms such as decreased serum platelet factor 4 and increased beta thromboglobulin have been found to be associated with poor prognosis (131).

Viral infections and sepsis generally trigger innate mechanisms such as activation of tissue factor, complement system $\mathrm{C} 3 \mathrm{a}$ and $\mathrm{C} 5 \mathrm{a}$, and von Willebrand factor (132-134).

Activation in the complement cascade activates leukocytes and the increased regional release of proinflammatory cytokines IL-1, IL-6, IL-8, and IFN-y leads to microvascular damage. In animal models of sepsis, inhibition of the complement system has been shown to improve coagulopathy and endothelial dysfunction (135). 
The strong antiplatelet and antithrombotic properties of quercetin known since the 1980s are mainly due to its inhibitory effects on cyclooxygenase and lipoxygenase activity in platelets. Lipid peroxides and superoxide anions inhibit prostacyclin and endothelium-derived relaxing factor (EDRF), which have antithrombotic effects. Quercetin shows antithrombotic and vasoprtective effects by increasing the local prostacyclin level and extending the half-life of EDRF (136).

In-vitro studies have shown that quercetin glycosides support thrombin inhibition by activating heparin cofactor II. A quercetin glycoside, quercetin 3,7,3',4'-tetrasulfate (QTS) has been shown to interact with thromboxane A2 to inhibit platelet aggregation, in-vivo. In addition, QTS has been observed to act as a fibrinolytic agent by inhibiting tissue factor expression in human monocyte cell culture. It was observed that QTS at $25 \mathrm{mg} / \mathrm{kg} / \mathrm{i} . \mathrm{p}$ had the same efficacy as acetyl salisilic asid used at $50 \mathrm{mg} / \mathrm{kg} / \mathrm{i} . p$. $(137,138)$.

A study done with biochemical and cytometric processes; demonstrated that quercetin and its metabolites suppressed platelet activation, dense granule secretion, fibrinogen binding to platelets via integrin $\alpha \mathrm{IIb} \beta 3$, and suppressed all thrombotic effects of platelets and thrombus formation by changing the intracellular ratio of calcium (139).

In another study in which the antiplatelet activity of quercetin was evaluated, it was demonstrated that platelet aggregation, granule secretion, ATP release and P-selectin expression were suppressed, platelet cAMP level and vasodilator-stimulatedphosphoprotein phosphorylation were increased. It has been observed to inhibit collagen, ADP and thrombin-induced platelet aggregation. It significantly attenuate thrombin evoked $[\mathrm{Ca} 2+]$ mobilization (140).

In a study with mice given $200 \mathrm{mg} / \mathrm{kg}$ isoquercetin, antithrombotic effects were demonstrated in-vivo over a period of 48 hours (141).

It was considered as a potential thrombin inhibitor in an in-vitro study in which 30 flavonoids, including quercetin, were evaluated for their antithrombin effects (142).

It is shown that quercetin reduces fibrinogen binding to activated integrin $\alpha \operatorname{IIb} \beta 3$. Integrin $\alpha \operatorname{IIb} \beta 3$ is directly related with adhesion and platelet activation. Quercetin is also known as an inhibitor of PI3K. PI3K plays a crucial role in platelet function such as activation, adhesion and aggregation, with Akt, the main target of PI3K signaling (143).

\section{Gut Microbiome and Dysbiosis}

High levels of proinflammatory cytokines secondary to viral infections can alter the intestinal microbiota and disrupt intestinal integrity. A small dysfunction in the small intestine activates a multifaceted mechanism, including the immune system, which results in microbiota changes and inflammation. Inflammation in the intestines causes an intestinal permeability that allows bacterial antigens and other toxins to pass into the systemic circulation, which may worsen the condition of patients diagnosed with COVID-19 in the septic picture.

Immune responses that develop in response to viral infections such as influenza can lead to consequences such as dysbiosis and increased intestinal permeability (144).

Secondary infections follow the microbial passage that develops due to permeability. Bacterial translocation from the intestine to the lungs has been reported in cases of sepsis and ARDS (145).

It is known that the intestines and lungs are interrelated to regulate the immune response and dysbiosis in the intestinal microbiota contributes to the pathogenesis of lung infections (146). Detection of SARS-CoV2 RNA in fecal sampes may support this transition (147).

In a study in which autopsy series of individuals infected with SARS-CoV were examined, pathological modifications were also observed in the digestive tract, indicating that virus-infected immune cells entered the circulation and damaged enteric cells (148).

These data suggest that coronaviruses can migrate from the lung tissue into the systemic circulation and migrate into intestinal cells through the circulation and lymphatic system.

Flavonoids have regulating and healing effects on microbiota. They suppress inflammation in the intestine. Flavonoids are metabolized by bacteria in the intestinal flora. Its regulatory effects on the intestinal immune system are also known (149).

It has been shown that quercetin supplementation has positive effects on microbiota biodiversity in mice whose microbiota has been modified by antbiotics. Their contributions to intestinal barrier property, villi length and mucosal thickness were also found to be statistically significant. This study demonstrated the healing power and prebiotic effect of quercetin on microbiota (150). 
The effect of trans-resveratrol and quercetin on intestinal microbiota was investigated in a study conducted on mice on a high fat / sucrose diet. With the addition of quercetin to the diet, positive changes were observed in the microbiota in addition to changes in the intestinal epithelial level. Quercetin produced an increase in the Firmicutes / Bacteroidetes ratio and some other positive changes in the gut microbiota in mice fed this high fat / sucrose diet. One of these changes is the significant reduction of Erysipelotrichaceae and Bacillus species, which are associated with western-type diets and obesity (151).

\section{CONCLUSION}

Quercetin may have beneficial effects by acting directly or indirectly on many parts of COVID-19 pathogenesis. It has been observed in many studies that it has anti-inflammatory, antioxidant, antithrombotic and immunoregulatory and microbiota-regulatory effects in COVID-19 as in some other viral diseases previously reviewed. Quercetin appears to be an important potentially powerful agent for both the treatment and prevention of COVID-19. Its properties to improve the immune system and mitochondrial functions make this valuable flavonoid an important alternative treatment option for COVID-19 alongside all the other candidate drugs. Further studies are needed not only on its efficacy but also on some properties such as dosage, duration of use, and which form to use.

\section{Declarations:}

\section{Conflicts of interest}

The authors declare no conflict of interests.

\section{Funding}

No funding sources for research.

\section{Author Contributions}

ŞT and HA carried out the literature survey together. ŞT wrote the manuscript. All authors read and approved the final manuscript.

\section{Ethical Statement}

Since the article was a review of studies in the literature, no ethical statement was required.

\section{REFERENCES}

1. Cunha CB, Opal SM. Middle East respiratory syndrome (MERS): a new zoonotic viral pneumonia. Virulence 2014;5(6):650-654. https://doi.org/10.4161/viru.32077

2. De Groot RJ, Baker SC, Baric RS et al. Middle east Rrespiratory yndrome coronavirus (MERS-
$\mathrm{CoV})$ : announcement of the Coronovirus Study. Group. JVirol 2013;87(14):7790-7792. https://doi.org/10.1128/JVI.01244-13

3. Velavan TP, Meyer CG. The COVID19 epidemic. Trop Med Int Health 2020;25(3):278-280. https://doi.org/10.1111/tmi.13383.

4. WHO Director-General's opening remarks at the media briefing on COVID-19. 11 March 2020.

https://www.who.int/dg/speeches/detail/whodirector-general-s-opening-remarks-at-themedia-briefing-on-covid-19---11-march-2020

5. Channappanavar R., Zhao J., Perlman S. T cellmediated immune response to respiratory coronaviruses. Journal. 2014;59:118-128. https://doi.org/10.1007/s12026-014-8534-z

6. Bosch, B. J., van der Zee, R., de Haan, C. A., \& Rottier, P. J. (2003). The coronavirus spike protein is a class I virus fusion protein: structural and functional characterization of the fusion core complex. Journal of virology, 77(16), $\quad 8801-8811$. https://doi.org/10.1128/jvi.77.16.88018811.2003

7. Chen Y., Guo Y., Pan Y., Zhao Z.J. Structure analysis of the receptor binding of 2019nCoV. Journal. 2020 https://doi.org/10.1016/j.bbrc.2020.02.071.

8. Hao X, Liang Z, Jiaxin , Jiakuan P, Hongxia D et al. High expression of ACE2 receptor of 2019-nCoV on the epithelial cells of oral mucosa. Int J Oral Sci 12,8 (2020). https://doi.org/10.1038/s41368-020-0074-х

9. Guan WJ, Ni ZY, Hu Y, Liang WH, Ou CQ, He JX, et al. Clinical Characteristics of Coronavirus Disease 2019 in China. N Engl J Med. 2020 382:1708-1720 https://doi.org/10.1056/NEJMoa2002032

10. Hamming I., Timens W., Bulthuis M.L., Lely A.T., Navis G., van Goor H. Tissue distribution of ACE2 protein, the functional receptor for SARS coronavirus. A first step in understanding SARS pathogenesis. Journal. Pathol 2004;203:631637. https://doi.org/10.1002/path.1570.

11. Jia, H. P., Look, D. C., Shi, L., Hickey, M., Pewe, L., Netland, J., Farzan, M., WohlfordLenane, C., Perlman, S., \& McCray, P. B., Jr (2005). ACE2 receptor expression and severe acute respiratory syndrome coronavirus infection depend on differentiation of human 
airway epithelia. Journal of virology, 79(23), 14614-14621.

https://doi.org/10.1128/JVI.79.23.1461414621.2005

12. Burak M \& Imen Y (1999) Flavonoids and their antioxidant properties. Turkiye Klin Tip Bil Derg 19, 296-304.

13. Cavalcante G.M., da Silva Cabral A.E., Silva C.C. Leishmanicidal Activity of Flavonoids Natural and Synthetic: A Minireview. Mintage J. Pharm. Med. Sci. (ISSN: 2320-3315), 2018;7:25-34. Retrieved from http://mjpms.in/index.php/ mjpms/article/view/317.

14. Takahashi, A., \& Ohnishi, T. (2004). The significance of the study about the biological effects of solar ultraviolet radiation using the Exposed Facility on the International Space Station. Uchu Seibutsu Kagaku, 18(4), 255260. https://doi.org/10.2187/bss.18.255

15. Dewick PM (2009) The shikimate pathway: aromatic amino acids and phenylpropanoids. In Medicinal Natural Products: a Biosynthetic Approach, 2nd ed., pp. 137186. https://doi.org/10.1002/9780470742761.c $\mathrm{h} 4$

16. Shan X., Cheng J., Chen K.1., Liu Y.M., Juan L. Comparison of Lipoxygenase, Cyclooxygenase, Xanthine Oxidase Inhibitory Effects and Cytotoxic Activities of Selected Flavonoids. DEStech Trans. Environ. Energy Earth Sci. 2017 https://doi.org/10.12783/dteees/gmee2017/166 24.

17. Kozłowska, A., Szostak-Wegierek, D. Flavonoids-food sources and health benefits. Rocz. Panstw. Zakl. Hig. (2014). 65(2), 79-85.

18. Ullah, A., Munir, S., Badshah, S. L., Khan, N., Ghani, L., Poulson, B. G., Emwas, A. H., \& Jaremko, M. (2020). Important Flavonoids and Their Role as a Therapeutic Agent. Molecules (Basel, Switzerland), 25(22), 5243. https://doi.org/10.3390/molecules25225243

19. Ovando C, Hernandez D, Hernandez E, et al. (2009) Chemical studies of anthocyanins: a review. Food Chem 113, 859-871. http://dx.doi.org/10.1016/j.foodchem.2008.09. 001

20. Lee, Y. K., Yuk, D. Y., Lee, J. W., Lee, S. Y., Ha, T. Y., Oh, K. W., Yun, Y. P., \& Hong, J. T. (2009). (-)-Epigallocatechin-3-gallate prevents lipopolysaccharide-induced elevation of betaamyloid generation and memory deficiency. Brain research, 1250, 164-174. https://doi.org/10.1016/j.brainres.2008.10.012

21. Zhao L., Yuan X., Wang J., Feng Y., Ji F., Li Z., Bian J. A review on flavones targeting serine/threonine protein kinases for potential anticancer drugs. Bioorganic Med. Chem. 2019;27:677-685. https://doi.org/10.1016/j.bmc.2019.01.027

22. Zhao K., Yuan Y., Lin B., Miao Z., Li Z., Guo Q., Lu N. LW-215, a newly synthesized flavonoid, exhibits potent anti-angiogenic activity in vitro and in vivo. Gene. 2018;642:533-541. https://doi.org/10.1016/j.gene.2017.11.065.

23. Metodiewa, D., Kochman, A., \& Karolczak, S. (1997). Evidence for antiradical and antioxidant properties of four biologically active N,Ndiethylaminoethyl ethers of flavanone oximes: a comparison with natural polyphenolic flavonoid (rutin) action. Biochemistry and molecular biology international, 41(5), 10671075.

https://doi.org/10.1080/15216549700202141

24. Walker, E. H., Pacold, M. E., Perisic, O., Stephens, L., Hawkins, P. T., Wymann, M. P., \& Williams, R. L. (2000). Structural determinants of phosphoinositide 3-kinase inhibition by wortmannin, LY294002, quercetin, myricetin, and staurosporine. Molecular cell, 6(4), 909$919 . \quad$ https://doi.org/10.1016/s10972765(05)00089-4

25. Camero C.M., Germanò M.P., Rapisarda A., D'Angelo V., Amira S., Benchikh F., Braca A., De Leo M. Anti-angiogenic activity of iridoids from Galium tunetanum. Rev. Bras. de Farmacogn. 2018;28:374-377.

https://doi.org/10.1016/j.bjp.2018.03.010

26. Mazidi M., Katsiki N., Banach M. A higher flavonoid intake is associated with less likelihood of nonalcoholic fatty liver disease: Results from a multiethnic study. J. Nutr. Biochem. 2019;65:66-71. https://doi.org/10.1016/j.jnutbio.2018.10.001.

27. Aguiar L.M., Geraldi M.V., Cazarin C.B.B., Junior M.R.M. Functional Food Consumption and Its Physiological Effects. Bioactive Compounds. Health Benefits and Potential Applications 2019, Pages 205-225. https://doi.org/10.1016/B978-0-12-814774$0.00011-6$ 
28. Panche A., Diwan A., Chandra S. Flavonoids: An overview. J. Nutr. Sci. 2016;5:e47. https://doi.org/10.1017/jns.2016.41

29. Khan M.K., Zill E.H., Dangles O. A comprehensive review on flavanones, the major citrus polyphenols. J. Food Compos. Anal. 2014;33:85-104.

https://doi.org/10.1016/j.jfca.2013.11.004.

30. Khalifa I., Zhu W., Li K.-k., Li C.-m. Polyphenols of mulberry fruits as multifaceted compounds: Compositions, metabolism, health benefits, and stability - A structural review. J. Funct. Foods. 2018;40:28-43. https://doi.org/10.1016/j.jff.2017.10.041

31. Iwashina T (2013) Flavonoid properties of five families newly incorporated into the order Caryophyllales (Review). Bull Natl Mus Nat Sci 39, 25-51. http://ci.nii.ac.jp/vol_issue/nels/AA12231458_ en.html

32. Kawabata, K., Mukai, R., Ishisaka, A. Quercetin and related polyphenols: new insights and implications for their bioactivity and bioavailability. Food Funct. 2015;6(5):1399-1417. https://doi.org/10.1039/C4FO01178C

33. Chun, OK., Chung, S-J., Claycombe, KJ., Song, WO. Serum C-reactive protein concentrations are inversely associated with dietary flavonoid intake in U.S. adults. J Nutr. 2008;138(4):753760. https://doi.org/10.1093/jn/138.4.753

34. Wang, W., Sun, C., Mao, L et al. The biological activities, chemical stability, metabolism and delivery systems of quercetin: a review. Trends in Food Sci Technol. 2016;56:21-38. https://doi.org/10.1016/j.tifs.2016.07.004

35. Kawai, Y . Understanding metabolic conversions and molecular actions of flavonoids in vivo: toward new strategies for effective utilization of natural polyphenols in human health. J Med Invest. 2018;65(3.4):162165. https://doi.org/10.2152/jmi.65.162

36. Davis, JM., Murphy, EA., Carmichael, MD. Effects of the dietary flavonoid quercetin upon performance and health. Curr Sports Med Rep. 2009;8(4):206-213. https://doi.org/10.1249/JSR.0b013e3181ae895 9

37. Dabeek, WM., Marra, MV. Dietary quercetin and kaempferol: bioavailability and potential cardiovascular-related bioactivity in humans.
Nutrients. 2019;11(10):2288. https://doi.org/1 $0.3390 /$ nu11102288

38. Li, Y., Yao, J., Han, $\mathrm{C}$ et al. Quercetin, inflammation and immunity. Nutrients. 2016;8(3):167. https://doi.org/10.33 90/nu8030167

39. Jafarinia, M., Sadat Hosseini, M., Kasiri, N et al. Quercetin with the potential effect on allergic diseases. Allergy Asthma Clin Immunol. 2020;16(1):36.

https://doi.org/10.1186/s13223-020-00434-0

40. Brito, AF., Ribeiro, M., Abrantes, AM et al. Quercetin in cancer treatment, alone or in combination with conventional therapeutics? Curr Med Chem. 2015;22(26):3025-3039.

https://doi.org/10.2174/0929867322666150812 145435

41. Dhiman, P., Malik, N., Sobarzo-Sánchez, E., Uriarte, E., Khatkar, A. Quercetin and related chromenone derivatives as monoamine oxidase inhibitors: targeting neurological and mental disorders. Molecules. 2019;24(3):418. https://doi.org/10.3390/molecules24030418

42. Chen, S., Jiang, H., Wu, X., Fang, J. Therapeutic effects of quercetin on inflammation, obesity, and type 2 diabetes. Mediators Inflamm. 2016;2016(3):1-5. https://doi.org/10.1155/2016/9340637

43. Veckenstedt, A., Güttner, J., Béládi, I. Synergistic action of quercetin and murine alpha/beta interferon in the treatment of Mengo virus infection in mice. Antiviral Res. 1987;7(3):169-178. https://doi.org/10.1016/0166-3542(87)900052

44. Agrawal PK, Agrawal C, Blunden G. Quercetin: Antiviral Significance and Possible COVID-19 Integrative Considerations https://doi.org/10.1177/1934578X20976293

45. De Palma, AM., Vliegen, I., De Clercq, E., Neyts, J. Selective inhibitors of picornavirus replication. Med Res Rev. 2008;28(6):823-884. https://doi.org/10.1002/med.20125

46. Ishitsuka, H., Ohsawa, C., Ohiwa, T, et al. Antipicornavirus flavone Ro 09-0179. Antimicrob Agents Chemother. 1982;22(4):611-616. https://doi.org/10.1128/AAC.22.4.611

47. Ganesan, S., Faris, AN., Comstock, AT et al. Quercetin inhibits rhinovirus replication in vitro and in vivo. 
Res. 2012;94(3):258-271.

https://doi.org/10.1016/j.antiviral.2012.03.005

48. Heinz, SA., Henson, DA., Austin, MD., Jin, F., Nieman, DC. Quercetin supplementation and upper respiratory tract infection: a randomized community clinical trial. Pharmacol Res. 2010;62(3):237-242.

https://doi.org/10.1016/j.phrs.2010.05.001

49. Hung, P-Y., Ho, B-C., Lee, S-Y et al. Houttuynia cordata targets the beginning stage of herpes simplex virus infection. PLoS One. 2015;10(2):e0115475. https://doi.org/10. 1371/journal.pone.0115475

50. El-Toumy, SA., Salib, JY., El-Kashak, WA et al. Antiviral effect of polyphenol rich plant extracts on herpes simplex virus type 1 . Food Sci Hum Wellness. https://doi.org/10.1016/j.fshw.2018.01.001

51. Nieman, DC., Henson, DA., Gross, SJ et al. Quercetin reduces illness but not immune perturbations after intensive exercise. Med Sci Sports Exerc. 2007;39(9):1561-1569. https://doi.org/10.1249/mss.0b013e318076b56 6

52. Chaabi, M . Antiviral effects of quercetin and related compounds. Naturopathic Currents, Special Edition, April 2020, Antiviral effects of quercetin and related compounds. https://naturopathiccurrents.com/s ites/default/files/AntiviralEffectsofQuercetinan dRelatedCompounds_0.pdf

53. Shinozuka, K., Kikuchi, Y., Nishino, C., Mori, A., Tawata, S. Inhibitory effect of flavonoids on DNA-dependent DNA and RNA polymerases. Experientia. 1988;44(10):882-885. https://doi.org/10.1007/BF01941188

54. Spedding, G., Ratty, A., Middleton, E. Inhibition of reverse transcriptases by flavonoids. Antiviral Res. 1989;12(2):99-110. https://doi.org/10.1016/0166-3542(89)90073-9

55. Colunga Biancatelli, RML., Berrill, M., Catravas, JD., Marik, PE. Quercetin and vitamin C: an experimental, synergistic therapy for the prevention and treatment of SARS-CoV2 related disease (COVID-19). Front Immunol. 2020;11:1451. https://doi.org/10.33 89/fimmu.2020.01451

56. Debiaggi, M., Tateo, F., Pagani, L., Luini, M., \& Romero, E. (1990). Effects of propolis flavonoids on virus infectivity and replication. Microbiologica, 13(3), 207-213.
57. Yi, L., Li, Z., Yuan, K et al. Small molecules blocking the entry of severe acute respiratory syndrome coronavirus into host cells. J Virol. 2004;78(20):11334-11339. https://doi.org/10.1128/JVI.78.20.1133411339.2004

58. Marra, MA., Jones, SJ., Astell, CR et al. The genome sequence of the SARS-associated coronavirus. Science. 2003;300(5624):13991404. https://doi.org/10.1126/science.1085953

59. Snijder, EJ., Bredenbeek, PJ., Dobbe, JC et al. Unique and conserved features of genome and proteome of SARS-coronavirus, an early split-off from the coronavirus group 2 lineage. $\mathrm{J}$ Mol Biol. 2003;331(5):991-1004. https://doi.org/10.1016/S0022-2836(03)008659

60. Chen, L., Li, J., Luo, $\mathrm{C}$ et al. Binding interaction of quercetin-3- $\beta$-galactoside and its synthetic derivatives with SARS-CoV 3CL(pro): structure-activity relationship studies reveal salient pharmacophore features. Bioorg Med Chem. 2006;14(24):8295-8306. https://doi.org/10.1016/j.bmc.2006.09.014

61. Zhang, L., Lin, D., Sun, $X$ et al. Crystal structure of SARS-CoV-2 main protease provides a basis for design of improved $\alpha$ ketoamide inhibitors.

Science. 2020;368(6489):409-412.

https://doi.org/10.1126/science.abb3405

62. Huang, F., Li, Y., Leung, E. L., Liu, X., Liu, K., Wang, Q., Lan, Y., Li, X., Yu, H., Cui, L., Luo, H., \& Luo, L. (2020). A review of therapeutic agents and Chinese herbal medicines against SARS-COV-2 (COVID-19). Pharmacological research, 158, 104929. https://doi.org/10.1016/j.phrs.2020.104929

63. Polansky, H., Lori, G., disease, C. Coronavirus disease 2019 (COVID-19): first indication of efficacy of Gene-Eden-VIR/Novirin in SARS$\mathrm{CoV}-2$ infection. Int $\mathrm{J}$ Antimicrob Agents. 2020;55(6):105971. https://doi.org/10. 1016/j.jjantimicag.2020.105971

64. Phillips, JM., Gallagher, T., Weiss, SR. Neurovirulent murine coronavirus jhm.sd uses cellular zinc metalloproteases for virus entry and cell-cell fusion. $\mathrm{J}$ Virol. 2017;91(8):1564-1576. https://doi.org/10.1128/JVI.01564-16

65. Han, Y-S., Chang, G-G., Juo, C-G et al. PapainLike protease 2 (PLP2) from severe acute respiratory syndrome coronavirus (SARS$\mathrm{CoV})$ : expression, purification, 
characterization, and inhibition. Biochemistry. 2005;44(30):10349-10359. https://doi.org/10.1021/bi0504761

66. Dabbagh-Bazarbachi, H., Clergeaud, G., Quesada, IM., Ortiz, M., O'Sullivan, CK., Fernández-Larrea, JB. Zinc ionophore activity of quercetin and epigallocatechin-gallate: from Hepa 1-6 cells to a liposome model. J Agric Food Chem. 2014;62(32):8085-8093. https://doi.org/10.1021/jf5014633

67. Alschuler, L., Weil, A., Horwitz, R et al. Integrative considerations during the COVID-19 pandemic. Explore. 2020;16(6):354-356. https://doi.org/10.1016/j.explore.2020.03.007

68. jo, S., Kim, H., Kim, S., Shin, DH., Kim, MS. Characteristics of flavonoids as potent MERS-CoV 3C-like protease inhibitors. Chem Biol Drug Des. 2019;94(6):2023-2030. https://doi.org/10.1111/cbdd.13604 31436895

69. Smith, M., Smith, JC. Repurposing therapeutics for COVID-19: Supercomputer-based docking to the SARS-CoV-2 viral spike protein and viral spike protein-human ACE2 interface. ChemRxiv. 2020.

70. Nguyen, TTH., Woo, H-J., Kang, H-K et al. Flavonoid-mediated inhibition of SARS coronavirus 3C-like protease expressed in Pichia pastoris. Biotechnol Lett. 2012;34(5):831-838. https://doi.org/10.1007/s10529-011-0845-8

71. Hui, DS., Azhar, EI., Madani, TA et al. The continuing 2019-nCoV epidemic threat of novel coronaviruses to global health - the latest 2019 novel coronavirus outbreak in Wuhan, China. International J. of Infect Dis. 2020;2020(91):264-266. https://doi.org/10.1016/j.ijid.2020.01.009

72. Glinsky G. V. (2020). Tripartite Combination of Candidate Pandemic Mitigation Agents: Vitamin D, Quercetin, and Estradiol Manifest Properties of Medicinal Agents for Targeted Mitigation of the COVID-19 Pandemic Defined by Genomics-Guided Tracing of SARS-CoV-2 Targets in Human Cells. Biomedicines, 8(5), 129.

https://doi.org/10.3390/biomedicines8050129

73. Ahmed, AK., Albalawi, YS., Shora, HA et al. Effects of quadruple therapy: zinc, quercetin, bromelain and vitamin $\mathrm{C}$ on the clinical outcomes of patients infected with COVID-19. Rea Int J of End and Diabe. 2020;1(1):018-021. https://doi.org/10.37179/rijed.000005
74. Chojnacka, K., Witek-Krowiak, A., Skrzypczak, D., Mikula, K., Młynarz, P. Phytochemicals containing biologically active polyphenols as an effective agent against Covid-19-inducing coronavirus. J Funct Foods. 2020;73:104146. https://doi.org/10.101 6/j.jff.2020.104146

75. Williamson, G., Kerimi, A. Testing of natural products in clinical trials targeting the SARSCoV-2 (Covid-19) viral spike proteinangiotensin converting enzyme-2 (ACE2) interaction.

Biochem Pharmacol. 2020;178:114123. https://doi.org/1 0.1016/j.bcp.2020.114123

76. Yoshikawa, T., Hill, T., Li, K., Peters, C. J., \& Tseng, C. T. (2009). Severe acute respiratory syndrome (SARS) coronavirus-induced lung epithelial cytokines exacerbate SARS pathogenesis by modulating intrinsic functions of monocyte-derived macrophages and dendritic cells. Journal of virology, 83(7), 3039-3048. https://doi.org/10.1128/JVI.0179208

77. Yuki, K., Fujiogi, M., \& Koutsogiannaki, S. (2020). COVID-19 pathophysiology: A review. Clinical immunology (Orlando, Fla.), 215, 108427. Advance online publication. https://doi.org/10.1016/j.clim.2020.108427

78. Huang C, Wang Y, Li X, Ren L, Zhao J et al. Clinical features of patients infected with 2019 novel coronavirus in Wuhan, China. Lancet (London, England) 2020; 395 (10223): 497$506 . \quad$ https://doi.org/10.1016/s01406736(20)30183-5

79. Crayne CB, Albeituni S, Nichols KE, Cron RQ. The immunology of macrophage activation syndrome. Frontiers in Immunology 2019; 10: 119.

https://doi.org/10.3389/fimmu.2019.00119

80. Wang $\mathrm{W}, \mathrm{He} \mathrm{J}$, Lie p, Huang $\mathrm{l}, \mathrm{Wu} \mathrm{S}$ et al. The definition and risks of cytokine release syndrome-like in 11 COVID19-infected pneumonia critically ill patients: disease characteristics and retrospective analysis. MedRxiv 2020. https://doi.org/10.1101/2020.02.26.20026989

81. Read M. A. (1995). Flavonoids: naturally occurring anti-inflammatory agents. The American journal of pathology, 147(2), 235237.

82. Manjeet K, R., \& Ghosh, B. (1999). Quercetin inhibits LPS-induced nitric oxide and tumor necrosis factor-alpha production in murine 
macrophages. International journal of immunopharmacology, 21(7), 435-443. https://doi.org/10.1016/s0192-0561(99)000247

83. Geraets, L., Moonen, H. J., Brauers, K., Wouters, E. F., Bast, A., \& Hageman, G. J. (2007). Dietary flavones and flavonoles are inhibitors of poly(ADP-ribose)polymerase-1 in pulmonary epithelial cells. The Journal of nutrition, 137(10), https://doi.org/10.1093/jn/137.10.2190

84. Bureau, G., Longpré, F., \& Martinoli, M. G. (2008). Resveratrol and quercetin, two natural polyphenols, reduce apoptotic neuronal cell death induced by neuroinflammation. Journal of neuroscience research, 86(2), 403-410. https://doi.org/10.1002/jnr.21503

85. Kim, H. P., Mani, I., Iversen, L., \& Ziboh, V. A. (1998). Effects of naturally-occurring flavonoids and biflavonoids on epidermal cyclooxygenase and lipoxygenase from guineapigs. Prostaglandins, leukotrienes, and essential fatty acids, 58(1), 17-24. https://doi.org/10.1016/s0952-3278(98)901259

86. Lee, K. M., Hwang, M. K., Lee, D. E., Lee, K. W., \& Lee, H. J. (2010). Protective effect of quercetin against arsenite-induced COX-2 expression by targeting $\mathrm{PI} 3 \mathrm{~K}$ in rat liver epithelial cells. Journal of agricultural and food chemistry, 58(9), https://doi.org/10.1021/jf903698s

87. Chirumbolo S. (2010). The role of quercetin, flavonols and flavones in modulating inflammatory cell function. Inflammation \& allergy drug targets, 9(4), 263-285. https://doi.org/10.2174/187152810793358741

88. Yang, D., Liu, X., Liu, M., Chi, H., Liu, J., \& Han, H. (2015). Protective effects of quercetin and taraxasterol against $\mathrm{H}_{2} \mathrm{O}_{2}$-induced human umbilical vein endothelial cell injury in vitro. Experimental and therapeutic medicine, 10(4), 1253-1260. https://doi.org/10.3892/etm.2015.2713

89. Huang, R.Y.; Yu, Y.L.; Cheng, W.C.; OuYang, C.N.; Fu, E.; Chu, C.L. Immunosuppressive effect of quercetin on dendritic cell activation and function. J Immunol June 15, 2010, 184 (12) 6815-6821. https://doi.org/10.4049/jimmunol.0903991

90. Cheng, S-C., Huang, W-C., S. Pang, J-H., Wu, Y-H., Cheng, C-Y et al. Quercetin inhibits the production of IL-1 $\beta$-induced inflammatory cytokines and chemokines in ARPE-19 cells via the MAPK and NF- $\kappa B$ signaling pathways. Int $\mathrm{J}$ Sci. 2019;20(12):2957. https://doi.org/10.3390/ ijms20122957

91. Nair, M. P., Kandaswami, C., Mahajan, S., Chadha, K. C., Chawda, R., Nair, H., Kumar, N., Nair, R. E., \& Schwartz, S. A. (2002). The flavonoid, quercetin, differentially regulates Th-1 (IFNgamma) and Th-2 (IL4) cytokine gene expression by normal peripheral blood mononuclear cells. Biochimica et biophysica acta, 1593(1),

29-36. https://doi.org/10.1016/s0167-4889(02)003282

92. Li, Y.; Yao, J.; Han, C.; Yang, J.; Chaudhry, M.T.; Wang, S.; Liu, H.; Yin, Y. Quercetin, Inflammation and Immunity. Nutrients 2016, 8, 167. https://doi.org/10.3390/nu8030167

93. Mehta, P., McAuley, DF., Brown, $\mathrm{M}$ et al. COVID-19: consider cytokine storm syndromes and immunosuppression. Lancet. 2020;395(10229):1033-1034. https://doi.org/10.1016/S0140-6736(20)306280

94. Ding, S., Xu, S., Ma, Y., Liu, G., Jang, H., Fang, J. Modulatory mechanisms of the NLRP3 inflammasomes in diabetes. Biomolecules. 2019;9(12):E850. https://doi.or $\mathrm{g} / 10.3390 /$ biom9120850

95. Chen, I-Y., Moriyama, M., Chang, M-F., Ichinohe, T. Severe acute respiratory syndrome coronavirus viroporin $3 \mathrm{~A}$ activates the NLRP3 inflammasome.

Front Microbiol. 2019;10:50. https://doi.org/10.3389 /fmicb.2019.00050

96. Lim, H., Min, DS., Park, H., Kim, HP. Flavonoids interfere with NLRP3 inflammasome activation. Toxicol Appl Pharmacol. 2018;355:93-102.

https://doi.org/10.1016/j.taap.2018.06.022

97. Cialdella-Kam, L., Nieman, D., Knab, A et al. A mixed Flavonoid-Fish oil supplement induces immune-enhancing and anti-inflammatory transcriptomic changes in adult obese and overweight women - A randomized controlled trial.

Nutrients. 2016;8(5):pii: E277. https://doi.org/10.3390/nu8050277

98. Nedoborenko, V. M., Kaidashev, I., Lavrenko, A., Vesnina, L., \& Mamontova, T. (2017). Inclusion of Quercetin in Treatment Reduces the Level of Interleukin 6 in Women with Iron Deficiency Anemia and Obesity. The Medical 
and Ecological Problems, 21(5-6), 37-39. Retrieved from https://ecomedjournal.org/index.php/journal/article/view/100

99. Kritas, SK., Ronconi, G., Caraffa, A et al. Mast cells contribute to coronavirus-induced inflammation: new anti-inflammatory strategy. J Biol Regul Homeost Agents. 2020;34(1):9-14. https://doi.org/10.23812/20-Editorial-Kritas

100. Weng, Z., Zhang, B., Asadi, S., Zuyi, W., Bodi, Z., Shahrzad, A et al. Quercetin is more effective than cromolyn in blocking human mast cell cytokine release and inhibits contact dermatitis and photosensitivity in humans. PLoS

One. 2012;7(3):e33805. https://doi.org/10.137 1/journal.pone.0033805

101. Shaik, Y., Caraffa, A., Ronconi, G., Lessiani, G., Conti, P. Impact of polyphenols on mast cells with special emphasis on the effect of quercetin and luteolin. Cent Eur $\mathrm{J}$ Immunol. 2018;43(4):476-481. https://doi.org/10.5114/ceji.2018.81347

102. Choudhary, S., Sharma, K., \& Silakari, O. (2020). The interplay between inflammatory pathways and COVID-19: A critical review on pathogenesis and therapeutic options. Microbial pathogenesis, 150, 104673. Advance online publication.

https://doi.org/10.1016/j.micpath.2020.104673

103. Schofield, J. H., \& Schafer, Z. T. (2021). Mitochondrial Reactive Oxygen Species and Mitophagy: A Complex and Nuanced Relationship. Antioxidants \& redox signaling, 34(7), 517-530. https://doi.org/10.1089/ars.2020.8058

104. Picca, A., Calvani, R., Coelho-Junior, H. J., Landi, F., Bernabei, R., \& Marzetti, E. (2020). Mitochondrial Dysfunction, Oxidative Stress, and Neuroinflammation: Intertwined Roads to Neurodegeneration. Antioxidants (Basel, Switzerland), 9(8), 647.

https://doi.org/10.3390/antiox9080647

105. Saleh, J., Peyssonnaux, C., Singh, K. K., \& Edeas, M. (2020). Mitochondria and microbiota dysfunction in COVID-19 pathogenesis. Mitochondrion, 54. https://doi.or g/10.1016/j.mito.2020.06.008

106. Zhang, Z., Rong, L., \& Li, Y. P. (2019). Flaviviridae Viruses and Oxidative Stress: Implications for Viral Pathogenesis. Oxidative medicine and cellular longevity, 2019, https://doi.org/10.1155/2019/1409582
107. Ivanov, A. V., Valuev-Elliston, V. T., Ivanova, O. N., Kochetkov, S. N., Starodubova, E. S., Bartosch, B., \& Isaguliants, M. G. (2016). Oxidative Stress during HIV Infection: Mechanisms and Consequences. Oxidative medicine and cellular longevity, 2016, 8910396.

108. Xu, Z., Shi, L., Wang, Y., Zhang, J., Huang, L., Zhang, C., Liu, S., Zhao, P., Liu, H., Zhu, L., Tai, Y., Bai, C., Gao, T., Song, J., Xia, P., Dong, J., Zhao, J., \& Wang, F. S. (2020). Pathological findings of COVID-19 associated with acute respiratory distress syndrome. The Lancet. Respiratory medicine, 8(4), 420-422. https://doi.org/10.1016/S2213-2600(20)30076$\mathrm{X}$

109. Zhou F, Yu T, Du R, Fan G, Liu Y, Liu Z, et al. Clinical course and risk factors for mortality of adult inpatients with COVID-19 in Wuhan, China: a retrospective cohort study. Lancet. 2020 Mar 28;395(10229):10541062 . https://doi.org/10.1016/S01406736(20)30566-3

110. Miripour, Z. S., Sarrami-Forooshani, R., Sanati, H., Makarem, J., Taheri, M. S., Shojaeian, F. (2020). Real-time diagnosis of reactive oxygen species (ROS) in fresh sputum by electrochemical tracing; correlation between COVID-19 and viral-induced ROS in lung/respiratory epithelium during this pandemic. Biosensors and Bioelectronics, 112435. https://doi.org/10.1016/j.bios.2020.11 2435

111. Ntyonga-Pono M. P. (2020). COVID-19 infection and oxidative stress: an underexplored approach for prevention and treatment?. The Pan African medical journal, 35(Suppl 2), 12. https://doi.org/10.11604/pamj.2020.35.2.22877

112. Tsujimoto, M., Yokota, S., Vilcek, J., \& Weissmann, G. (1986). Tumor necrosis factor provokes superoxide anion generation from neutrophils. Biochemical and biophysical research communications, 137(3), 1094-1100. https://doi.org/10.1016/0006-291x(86)90337-2

113. Kharazmi, A., Nielsen, H., Rechnitzer, C., \& Bendtzen, K. (1989). Interleukin 6 primes human neutrophil and monocyte oxidative burst response. Immunology letters, 21(2), 177-184. https://doi.org/10.1016/0165-2478(89)90056-4

114. Colston, J. T., Chandrasekar, B., \& Freeman, G. L. (2002). A novel peroxideinduced calcium transient regulates interleukin- 
6 expression in cardiac-derived fibroblasts. The Journal of biological chemistry, 277(26), 23477-23483.

https://doi.org/10.1074/jbc.M108676200

115. J. Wu, Tackle the free radicals damage in COVID-19, Nitric Oxide, https:// doi.org/10.1016/j.niox.2020.06.002.

116. Prochazkova D., Bousova I., Wilhelmova N. Antioxidant and prooxidant properties of flavonoids. Fitoterapia. 2011;82:513-523. https://doi.org/10.1016/j.fitote.2011.01.018.

117. Terao J. Factors modulating bioavailability of quercetin-related flavonoids and the consequences of their vascular function. Biochem. Pharmacol. 2017;139:1523. https://doi.org/10.1016/j.bcp.2017.03.021.

118. Shu Z., Yang Y., Yang L., Jiang H., Yu X., Wang Y. Cardioprotective effects of dihydroquercetin against ischemia reperfusion injury by inhibiting oxidative stress and endoplasmic reticulum stress-induced apoptosis via the PI3K/Akt pathway. Food Funct. 2019;10:203-215.

https://doi.org/10.1039/C8FO01256C.

119. Terao J. (1999). Dietary flavonoids as antioxidants in vivo: conjugated metabolites of (-)-epicatechin and quercetin participate in antioxidative defense in blood plasma. The journal of medical investigation : JMI, 46(3-4), 159-168.

http://www.ncbi.nlm.nih.gov/pubmed/1068731 0

120. Awad, HM., Boersma, MG., Vervoort, J., Rietjens, IM., Vervoort Rietjens, JIM. Peroxidase-catalyzed formation of quercetin quinone methide-glutathione adducts. Arch Biochem Biophys. 2000;378(2):224-233. https://doi.org/10.1006/abbi.2000.1832

121. Kumar, P., Khanna, M., Srivastava, V et al. Effect of quercetin supplementation on lung antioxidants after experimental influenza virus infection. Exp Lung Res. 2005;31(5):449-459. https://doi.org/10.1080/019021490927088

122. Milea Ș.-A., Aprodu I., Vasile A.M., Barbu V., Râpeanu G., Bahrim G.E., Stănciuc N. Widen the functionality of flavonoids from yellow onion skins through extraction and microencapsulation in whey proteins hydrolysates and different polymers. J. Food Eng. 2019;251:29-35.

https://doi.org/10.1016/j.jfoodeng.2019.02.003
123. Pucciarini L., Ianni F., Petesse V., Pellati F., Brighenti V., Volpi C., Gargaro M., Natalini B., Clementi C., Sardella R. Onion (Allium cepa L.) Skin: A Rich Resource of Biomolecules for the Sustainable Production of Colored Biofunctional

Textiles. Molecules. 2019;24:634.

https://doi.org/10.3390/molecules24030634.

124. Yang S.J., Paudel P., Shrestha S., Seong S.H., Jung H.A., Choi J.S. In vitro protein tyrosine phosphatase 1B inhibition and antioxidant property of different onion peel cultivars: A comparative study. Food Sci. Nutr. 2019;7:205-215.

https://doi.org/10.1002/fsn3.863.

125. Ozolina, A., Sarkele, M., Sabelnikovs, O., Skesters, A., Jaunalksne, I., Serova, J., Ievins, T., Bjertnaes, L. J., \& Vanags, I. (2016). Activation of Coagulation and Fibrinolysis in Acute Respiratory Distress Syndrome: A Prospective Pilot Study. Frontiers in medicine, 3 , https://doi.org/10.3389/fmed.2016.00064

126. Idell S. (2003). Coagulation, fibrinolysis, and fibrin deposition in acute lung injury. Critical care medicine, 31(4 Suppl), S213-S220.

https://doi.org/10.1097/01.CCM.0000057846.2 1303.AB

127. Gaertner, F., \& Massberg, S. (2016). Blood coagulation in immunothrombosis-At the frontline of intravascular immunity. Seminars in immunology, 28(6), 561-569. https://doi.org/10.1016/j.smim.2016.10.010

128. Ranucci, M., Ballotta, A., Di Dedda, U., Bayshnikova, E., Dei Poli, M., Resta, M., Falco, M., Albano, G., \& Menicanti, L. (2020). The procoagulant pattern of patients with COVID19 acute respiratory distress syndrome. Journal of thrombosis and haemostasis : JTH, 18(7), 1747-1751. https://doi.org/10.1111/jth.14854

129. Hanff, T. C., Mohareb, A. M., Giri, J., Cohen, J. B., \& Chirinos, J. A. (2020). Thrombosis in COVID -19. American Journal of Hematology. https://doi.org/10.1002/ajh.25982

130. . Grimes, Z., Bryce, C., Sordillo, E. M., Gordon, R. E., Reidy, J., Paniz Mondolfi, A. E., \& Fowkes, M. (2020). Fatal Pulmonary Thromboembolism in SARS-CoV-2Infection. Cardiovascular pathology : the official journal of the Society for 
Cardiovascular Pathology, 48, 107227. https://doi.org/10.1016/j.carpath.2020.107227

131. Ng, L. F., Hibberd, M. L., Ooi, E. E., Tang, K. F., Neo, S. Y., Tan, J., Murthy, K. R., Vega, V. B., Chia, J. M., Liu, E. T., \& Ren, E. C. (2004). A human in vitro model system for investigating genome-wide host responses to SARS coronavirus infection. BMC infectious diseases, 4, 34. https://doi.org/10.1186/14712334-4-34

132. Poon, T. C., Pang, R. T., Chan, K. C., Lee, N. L., Chiu, R. W., Tong, Y. K., Chim, S. S., Ngai, S. M., Sung, J. J., \& Lo, Y. M. (2012). Proteomic analysis reveals platelet factor 4 and beta-thromboglobulin as prognostic markers in severe acute respiratory syndrome. Electrophoresis, 33(12), 1894 1900. https://doi.org/10.1002/elps.201200002

133. Subramaniam, S., \& Scharrer, I. (2018). Procoagulant activity during viral infections. Frontiers in bioscience (Landmark edition), 23, 1060-1081. https://doi.org/10.2741/4633

134. Lupu, F., Keshari, R. S., Lambris, J. D., \& Coggeshall, K. M. (2014). Crosstalk between the coagulation and complement systems in sepsis. Thrombosis research, 133 Suppl 1(0 1), S28-S31.

https://doi.org/10.1016/j.thromres.2014.03.014

135. Gragnano, F., Sperlongano, S., Golia, E., Natale, F., Bianchi, R., Crisci, M., Fimiani, F., Pariggiano, I., Diana, V., Carbone, A., Cesaro, A., Concilio, C., Limongelli, G., Russo, M., \& Calabrò, P. (2017). The Role of von Willebrand Factor in Vascular Inflammation: From Pathogenesis to Targeted Therapy. Mediators of inflammation, 2017, https://doi.org/10.1155/2017/5620314

136. Gryglewski, R. J., Korbut, R., Robak, J., \& Święs, J. (1987). On the mechanism of antithrombotic action of flavonoids. Biochemical Pharmacology, 36(3), 317322. doi:10.1016/0006-2952(87)90288-7

137. Guglielmone, H. A., Nuñez-Montoya, S. C., Agnese, A. M., Pellizas, C. G., Cabrera, J. L., \& Donadio, A. C. (2012). Quercetin $3,7,3^{\prime}, 4^{\prime}$-tetrasulphated isolated from Flaveria bidentis inhibits tissue factor expression in human monocyte. Phytomedicine, 19(12), 1068

1071. doi:10.1016/j.phymed.2012.06.013

138. Guglielmone, H. A., Agnese, A. M., Nuñez-Montoya, S. G., Cabrera, J. L., \&
Cuadra, G. R. (2020). Antithrombotic "in vivo"

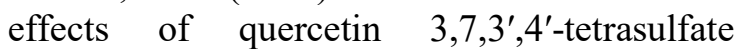
isolated from Flaveria bidentis in an experimental thrombosis model in mice. Thrombosis

Research. doi:10.1016/j.thromres.2020.07.040

139. Stainer, A. R., Sasikumar, P., Bye, A. P., Unsworth, A. J., Holbrook, L. M., Tindall, M., Lovegrove, J. A., \& Gibbins, J. M. (2019). The Metabolites of the Dietary Flavonoid Quercetin Possess Potent Antithrombotic Activity, and Interact with Aspirin to Enhance Antiplatelet Effects. TH open : companion journal to thrombosis and haemostasis, 3(3), e244-e258. https://doi.org/10.1055/s-0039-1694028

140. Oh, W. J., Endale, M., Park, S. C., Cho, J. Y., \& Rhee, M. H. (2012). Dual Roles of Quercetin in Platelets: Phosphoinositide-3Kinase and MAP Kinases Inhibition, and cAMP-Dependent Vasodilator-Stimulated Phosphoprotein Stimulation. Evidence-based complementary and alternative medicine : eCAM, 2012, 485262 . https://doi.org/10.1155/2012/485262

141. Rivera, J., Lozano, M. L., Navarro-Núñez, L., \& Vicente, V. (2009). Platelet receptors and signaling in the dynamics of thrombus formation. Haematologica, 94(5), 700-711. https://doi.org/10.3324/haematol.2008.003178

142. Liu, L., Ma, H., Yang, N., Tang, Y., Guo, J., Tao, W., \& Duan, J. (2010). A Series of Natural Flavonoids as Thrombin Inhibitors: Structureactivity relationships. Thrombosis Research, 126(5), e365-e378. Rivera, J., Lozano, M. L., Navarro-Núñez, L., \& Vicente, V. (2009). Platelet receptors and signaling in the dynamics of thrombus formation. Haematologica, 94(5), 700-711.

https://doi.org/10.3324/haematol.2008.003178 10.1016/j.thromres.2010.08.006

143. Smyth, S. S., Woulfe, D. S., Weitz, J. I., Gachet, C., Conley, P. B., ... Goodman, S. G. (2008). G-Protein-Coupled Receptors as Signaling Targets for Antiplatelet Therapy. Arteriosclerosis, Thrombosis, and Vascular Biology, 29(4), 449457. doi:10.1161/atvbaha.108.176388

144. Wang J, Li F, Wei H, Lian ZX, Sun R et al. (2014). Respiratory influenza virus infection induces intestinal immune injury via microbiotamediated Th17 cell-dependent inflammation. Journal of Experimental Medicine $211 \quad$ (12): 2397-2410. https://doi.org/10.1084/jem.20140625 
145. Dickson RP, Singer BH, Newstead MW, Falkowski NR, ErbDownward JR et al. (2017). Enrichment of the lung microbiome with gut bacteria in sepsis and the acute respiratory distress syndrome. Nature Microbiology 1 (10): 16113. nmicrobiol.2016.113

146. Fanos V, Pintus MC, Pintus R, Marcialis MA (2020). Lung microbiota in the acute respiratory disease: from coronavirus to metabolomics. Journal of Pediatric and Neonatal Individualized Medicine 9 (1): 90139. https://doi.org/10.7363/090139

147. Wu Y, Guo C, Tang L, Hong Z, Zhou J et al. (2020). Prolonged presence of SARS-CoV-2 viral RNA in faecal samples. Lancet Gastroenterology and Hepatology 5 (5): 434$435 . \quad$ https://doi.org/10.1016/ S24681253(20)30083-2

148. Aktas, B., \& Aslim, B. (2020). Gut-lung axis and dysbiosis in COVID-19. Turkish journal of biology $=$ Turk biyoloji dergisi, 44(3), 265-272. https://doi.org/10.3906/biy-2005-102

149. Pei, R., Liu, X., \& Bolling, B. (2020). Flavonoids and gut health. Current Opinion in Biotechnology, 61, 153159. https://doi.org/10.1016/j.copbio.2019.12.0 18

150. Shi T, Bian X, Yao Z, et al. Quercetin improves gut dysbiosis in antibiotic-treated mice. Food \& Function. 2020 Sep;11(9):80038013. https://doi.org/10.1039/d0fo01439g.

151. Etxeberria, U., Arias, N., Boqué, N., Macarulla, M. T., Portillo, M. P., Martínez, J. A., \& Milagro, F. I. (2015). Reshaping faecal gut microbiota composition by the intake of transresveratrol and quercetin in high-fat sucrose diet-fed rats. The Journal of Nutritional Biochemistry, 26(6), 651660. https://doi.org/10.1016/j.jnutbio.2015.01. 002 